\title{
The Cascade Model of Mathematics Teachers' Professional Development in South Africa: How Well did it Suit Them?
}

\author{
Benard Chigonga ${ }^{1 *}$, Paul Mutodi ${ }^{1}$ \\ ${ }^{1}$ University of Limpopo, Sovenga, SOUTH AFRICA
}

Received 13 June 2018 - Revised 27 December 2018 • Accepted 20 January 2019

\begin{abstract}
This paper discusses the extent to which the professional development (cascade model) met its goal of improving mathematics teaching and learning during the implementation of National Curriculum Statement in South Africa. Fifty mathematics teachers from ten public secondary schools in Vhembe District in Limpopo Province of South Africa were chosen purposively. Using a qualitative approach, data were collected through a focus group discussion with five mathematics teachers at each of the ten schools. Teachers disapproved the manner in which the workshops were conducted claiming that they were disconnected from classroom practices. The conclusion was that: (a) the success of in-service programs should be determined by the way that the ideas, knowledge and skills learnt are implemented in a classroom setting; (b) for any in-service program that introduces teachers to a different instructional approach from the traditional one, it has to impact on teachers' concerns (be they self-oriented, task-oriented or impact-oriented).
\end{abstract}

Keywords: cascade model, lesson study, national curriculum statement implementation, professional development

\section{INTRODUCTION}

Although professional development is not the panacea for all educational effort to enhance teaching and learning (Ono \& Ferreira, 2010), it is "viewed as a critical component of reform, one that must be linked to those same clear goals for students, assessment, pre-service teacher education, school leadership, and resources and staffing" (Loucks-Horsley et al., 2010: 78).

Since the inception of the National Curriculum Statement (NCS) in the Further Education and Training (FET) band in 2006 in South Africa, there is dearth in knowledge on the impact of traditional in-service teacher professional development programs in mathematics teaching and learning. These teacher professional development programs are often provided through workshops. The Minister of Basic Education, (quoted in the Periodical Teachers' News Letter, October 2010) revealed that Limpopo, KwaZulu-Natal and the Eastern Cape are home to the majority of the country's most dysfunctional schools. She added that these dysfunctional schools recorded the worst pass rates in the 2009 matriculation examinations. Motshekga further indicated that a total of 506 schools across the country achieved pass rates between $0 \%$ and $20 \%$ in the 2009 matriculation examination. Limpopo tops the list, with 186 of these dysfunctional schools.

Teachers institute a significant aspect of a school's instructional capacity. Therefore, the key to school improvement has been marked by defining the roles of the teacher (McAleavy, \& Elwick, 2016). This development hinges on the understanding that any substantial progress in student learning must depends on the teacher (Van Tassel-Baska, 2005). Heck (2007) reiterate that it is the "intellectual ability, knowledge and skills of the individuals involved in the teaching and learning tasks that impact on job performance and effectiveness in the classroom" (p.405). Stronge (2007) stresses that "not only the presence or absence of teachers that makes a difference, but also the teachers who are competent in content, pedagogy and assessment of their subject area" (p.38). Furthermore, Heck (2009) attests that "teacher effectiveness is an individual resource that varies across classrooms within a

(C) 2019 by the authors; licensee Modestum Ltd., UK. This article is an open access article distributed under the terms and conditions of the Creative Commons Attribution License (http://creativecommons.org/licenses/by/4.0/). \benardchigonga@gmail.com (*Correspondence) 《 paul.mutodi2@ul.ac.za 


\section{Contribution of this paper to the literature}

- There is a scarcity in knowledge about the extent to which professional development (cascade model) met its intended goal of improving mathematics teaching and learning in the implementation of National Curriculum Statement, South Africa.

- Providing decision-makers and stakeholders with the first-hand data that they need to rethink and reorganize a flexible and sustainable approach addressing the teacher professional development discrepancies.

- Shedding light on the need to readjust the aims of in-service and teacher education programs, in order to make them appropriate and suitable to the novel curriculum.

school, as well as a collective resource that varies across schools" (p.235). Therefore, according to Lee (2007), effective models of professional development may minimize the teacher dissimilarities to the extent that each student is catered for in the process of teaching and learning.

Nevertheless, the inception of Outcome Based Education (OBE) and Curriculum 2005 (C2005) was an exceptional curriculum change in South Africa. There was a huge gap at the time between the aims of OBE and C2005 and what the majority of teachers had been trained for (Jansen \& Taylor, 2003). It was a challenge for many South African teachers who had inadequate knowledge, skills and competence and who relied on teacher talk and rote memory as the predominant mode of teaching and learning (Jansen \& Christie, 1999). Because OBE differs from previous practice, one would imagine that intensive and extensive professional teacher development would be necessary to prepare teachers for the implementation of OBE (Fiske \& Ladd, 2004). However, training of teachers for OBE was inadequate (Jansen \& Christie, 1999; Jansen \& Taylor, 2003; Taylor \& Vinjevold, 1999). Rather than mounting a series of professional development programs that were collaborative in nature and based on teachers' contexts, the Department of Education (DoE) adopted a "cascade" model. This model entailed district curriculum advisors training a number of circuit subject advisors in a particular content, and they then had to workshop teachers (Hunzicker, 2011; Kennedy, 2005). Some teachers even lamented that the subject advisors sometimes failed to understand the curriculum. That way, the result was the "watering down or misinterpretation of crucial information" (Fiske \& Ladd, 2004: 162). The inclination for the cascade model is that it is cheap and can spread out to a lot of teachers within a short time, although researchers have criticized this model for its noticeable inadequacies (Bett, 2016). On the contrary, professional development that occupies teachers in learning activities that are supportive, job-embedded, instructionally focused, collaborative, and ongoing have been found to be effective than those that are not. This is so because curriculum is usual done prior to its use. Nevertheless, student and teacher use of the designed material encompasses the actual or effective curriculum -, hence the need for effective professional development to teach teachers how to use these materials. In relation to this, the argument is that different strategies of professional development could be more suitable for teachers based on the stage they are in the implementation of NCS. For instance, at the commencement of the implementation of the NCS, "teachers may need concrete information first about what they will learn and its purpose. As they learn, they want more how-to advice and images of what the practices look like in real classrooms. Later, they want ways to collaborate with others on the use of the practice and to assess the impact on students" (Easton, 2009). This argument has led to an interest in exploring the extent to which traditional in-service teacher professional development archived its goal of enhancing mathematics teaching and learning during the implementation of NCS.

From the above premises, the report is on a study whose aim is to elucidate the extent to which in-service teacher professional development meets the intended goal of improving mathematics teaching and learning during the implementation of NCS. In doing so, a focus group discussion with five mathematics teachers at each of the ten schools was conducted. The goal of the discussions was to obtain descriptions on the conditions under which mathematics teachers were exposed to professional development before and during NCS implementation in order to access its effect on Mathematics teaching and learning. Therefore, the study responded to the question: to what extent was teacher professional development relevant to the Mathematics teaching and learning during the implementation of NCS?

One hopes that the exposition of the outcomes of this study to the powers that be might help to readjust the goals of teacher education and teacher in-service programs, so that they become relevant to the novel curriculum. Now, literature review and methodology will first be presented. This is followed by the results and discussion. Conclusion is done by stressing the findings of this study and recommendation.

\section{REVIEW OF LITERATURE}

Literature review answered the question: What are the characteristics of effective and relevant professional development for in-service teachers? Attention was given to the guides for designing professional development of 


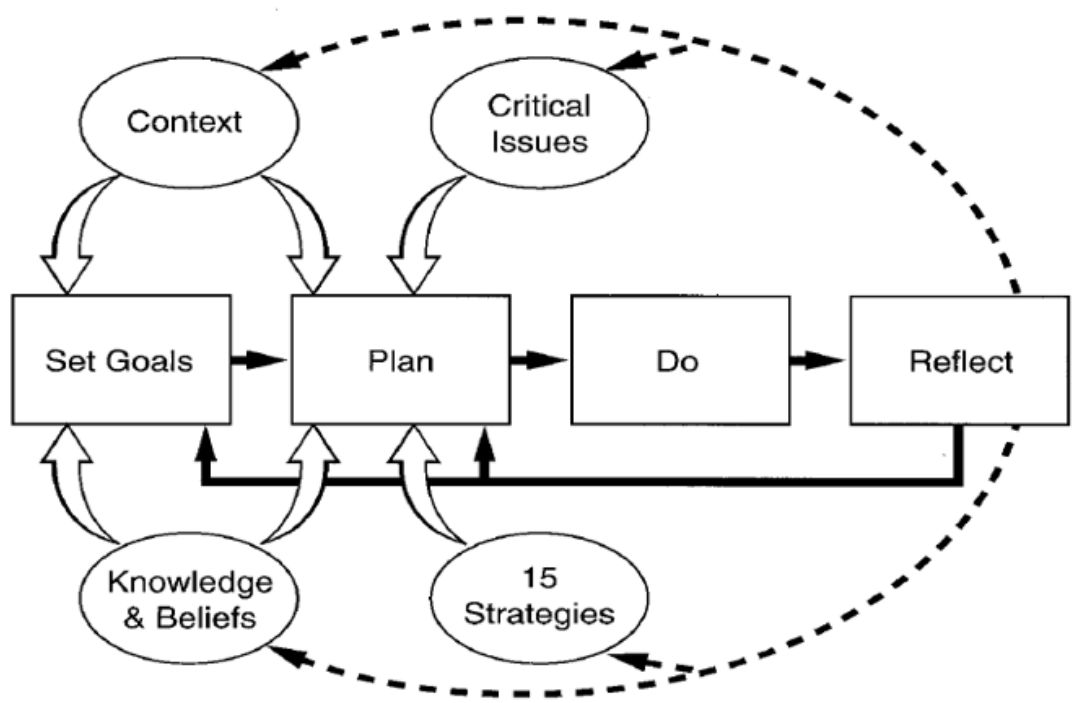

Figure 1. The Professional Development Design Framework (Loucks-Horsley, et al., 1998)

Hunzicker (2011) and Easton (2009)'s Concerns-Based Adoption Model (CBAM) and the characteristics of lesson study as an effective professional development activity.

Hunzicker (2011: 178) suggests that effective teacher professional development should be:

- Supportive: it considers the needs, concerns and interests of individual teachers along with those of the school.

- Job-embedded: making it relevant and authentic.

- Instructionally focused: which involves the study and application of content and pedagogy with emphasis on student Learning Outcomes.

- Collaborative: engaging teachers in both active and interactive learning.

- Ongoing: a combination of contact hours, duration and coherence.

With these characteristics of professional development in place, teachers are more likely to consider it relevant and authentic, which is more likely to result in teacher learning and improved teaching practice (Hunzicker, 2011). Therefore, teacher professional development becomes relevant when it connects to teachers' daily responsibilities and becomes authentic when it is incorporated into each school day, engaging teachers in activities such as coaching, mentoring and study groups (Hunzicker, 2011; Meijs, Prinsen, \& de Laat, 2016). This assumption seems to be realistic in that it calls for a professional development design framework as illustrated in Figure 1.

CBAM is also a guide for crafting professional development. CBAM defines the evolving teacher concerns as they are presented to novel practices (Donnell \& Gettinger, 2015). The concerns emanate from queries that are selforiented (e.g., "What is it?" "How will it affect me?" and "What will I have to do?"), to those that are task-oriented (e.g., "How can I get more organized?" "Why is it taking so much time?" and "How can I best manage the materials and schedules?"), and finally, when these concerns begin to be resolved, to more impact-oriented concerns (e.g., "How is this affecting students?" and "How can I improve what I am doing so all students can learn?") (Easton, 2009). The CBAM model subscribes to the notion that teacher concerns can point to the choice of approaches for professional development and offer awareness into the nature of the approaches in order to solve teachers' requirements during stages of the implementation of new program (Easton, 2009; Salleh, 2016). For instance, if the objective of the professional development is to improve teachers' content knowledge, the designer might first offer teachers an engagement experience in mathematics content. Subsequently, might offer workshops that help raise teachers' consciousness of what novel teaching practices look like in action (Gaudin \& Chaliès, 2015; Tam, 2015). As they implement new practice in the classrooms, they must meet with other teachers to deliberate on what is working and how to make improvements, thereby increasing their understanding and their skills (Trust \& Horrocks, 2017).

How can Impact-oriented questions of teachers be addressed? The impact-oriented concerns are as a results of the self- and task-oriented concerns. Therefore, the impact-oriented questions of teachers can be addressed by creating opportunities for them to scrutinize student work or to carry out action research into their own concerns about student learning. Throughout these latter stages of learning, teachers are usually involved in scrutinizing their experiences in the classroom, evaluating the effect of the variations they effected on their students, and looking at ways to improve (Attard, 2017). At this stage in their learning, teachers examine the practice of others, connecting 
it to what they do and coming up with thoughts for refinement (Meijs et al., 2016), which are features comparable to those of lesson study.

Lesson study is a form of classroom research in which a group of teachers examine teaching and learning in the milieu of an actual single class lesson (Lewis, 2008). When the teachers finish the study, they write a report that defines the lesson they planned and describes how the lesson worked and what they learnt about teaching and learning from the lesson study experience. According to Ono and Ferreira (2010), the prominent characteristic of lesson study is that "teachers are collaboratively engaged in action research in order to improve the quality of instruction" (p.7). The three phases of lesson study are collectively referred to as "plan-do-see" (Ono, 2008). Ono and Ferreira (2010) summarized lesson study as an activity characterized as "classroom-situated, context-based, student-focused, improvement-oriented, collaborative and teacher-owned" (p.6). As such, lesson study is described as a strategy that aims at establishing a professional learning communities where study groups, coaching by peers and lessons demonstration are useful strategies in professional development (Association for Supervision and Curriculum Development [ASCD], 2010; Salleh, 2016; Trust \& Horrocks, 2017).

\section{The Process of Lesson Study}

The process of lesson study is multifaceted. However, the process of lesson study, as a form of professional development, seeks to improve the degree to which the teacher can appropriately integrate the use of instruction techniques with the mathematics concept being taught and its effectiveness for learning (Shulman, 1986). In this case, attention is given to the growth of teachers' mathematical knowledge in teaching: knowledge about mathematics; knowledge about ways of teaching mathematics; and knowledge about the ways in which learners engage with and make sense of mathematics (Joubert \& Sutherland, 2008). Therefore, the main idea of this practice of lesson study is that a group of teachers discuss the content of the lesson, both what it means to acquire understanding of it and how it can be approached in teaching (Gunnarsdóttir \& Pálsdóttir, 2010; Hord \& Tobia, 2015). One teacher in the group then teaches this lesson while it is videoed and others observe student responses to the lesson. The group then meet to discuss the observed lesson in order to refine it guided by student responses and as a result re-teach a different cohort of students (Gunnarsdóttir \& Pálsdóttir, 2010; Hord \& Tobia, 2015). The intention of the process is often to deepen participants' understanding of the content and potential teaching styles (Covay Minor, Desimone, Caines Lee \& Hochberg, 2016). Subsequently, doing lesson study cycle provokes teachers to mirror on their own styles of teaching and learning and improve their practices in their working contexts (Attard, 2017). Hence, this view draws our attention to consider lesson study as a possible vehicle for successful professional development endeavors.

\section{METHODOLOGY}

\section{Design}

The paper is conceptualized around the belief that views inform practice (Krathwohl, 2004). Guided by this view, the study sought to discover and define the conditions under which mathematics teachers were exposed to professional development before and during NCS implementation. Student performance in Mathematics remain deplorable nationally. Hence, the teachers who had already gone through the professional development exercise were investigated retrospectively to identify what they gained which has a bearing on their current teaching practice in Mathematics. This may, in turn, help explain the degree to which professional development of mathematics teachers met its intended goal of improving mathematics teaching and learning during the implementation of NCS and suggest possible modes of professional development (such as lesson study) that best suit their situations. Thus providing an opportunity to generalise the study findings to the Vhembe District schools (Lodico, Spaulding, \& Voegtle, 2006). To achieve this, the study used qualitative research approach employing descriptive survey design. Using a descriptive survey design allowed for the exploration of an in-depth understanding (Krathwohl, 2004) of the degree to which professional development of mathematics teachers met its intended goal of improving mathematics teaching and learning during the implementation of NCS.

\section{Sample}

The participants were selected using criterion-based sampling method (Heppner \& Heppner, 2004). The criteria in this study were as follows: Participants were from five low-performing and five high-performing public secondary schools in the Vhembe District based on the pass rates in mathematics in high stakes examinations in 2008-2009 and must have 3 or more years teaching Mathematics. The participants consisted of 25 from five lowperforming and 25 from five high-performing schools ( $n=50,30$ males and 20 females). 


\section{Instrument}

Data were gleaned through a focus group discussion with five mathematics teachers at each of the ten schools. The aim of discussion was to discover the conditions the teachers of mathematics were exposed to professional development before and during NCS implementation. A pilot study with five mathematics teachers, involving usage of the loosely structured open-ended questions for discussion, was conducted at one school in Vhembe District. The discussion procedure was acceptable in terms of politeness, precision, pacing and importance of what was covered in the open-ended questions.

\section{Data Collection}

A focus group discussion with five mathematics teachers at each of the ten schools was conducted. The duration of the discussion ranged from 40 to 65 minutes and were audiotaped, with participants' consent, for later explanation (Creswell \& Clark, 2017). The language used in the discussions was English. The goal of the discussions was to obtain descriptions of the conditions the teachers of mathematics were exposed to professional development before and during NCS implementation in order to draw conclusions. The discussions involved the use of openended questions. The leading question was: how would you describe the preparation you went through for the implementation of NCS? Therefore, the discussion included questions concerning: modes of professional developments attended: the impact of such training to their teaching; what support teachers receive/ anticipate from the principal or Head of Department or curriculum advisor of mathematics; the modes of professional development that best suits their situations.

\section{Ethical Issues}

Permission to use selected sites was granted from the education managers from the district and principals. Dishonesty was guarded against during data processing.

\section{Data Analysis}

Data analysis began by listening to each audiotaped discussion in order to get a sense of the whole session (Creswell \& Clark, 2017). Raw data were obtained for further analysis by creating a transcript of each audiotaped discussion. After transcription was complete, the researcher read each transcript several times in order to create familiarity with the text (Colaizzi, 1978). Data collected from focus group discussions were transcribed and analysed using 1) open coding where I read line by line (Giorgi, 1985; Strauss \& Corbin, 1998) and significant statements were written down; 2) axial coding by putting together related statements and comparing each statement to generate sub-themes (Shank, 2006); and 3) selective coding where I related the sub-themes to each other and identified commonalities to form themes in relation to the purpose of the study (Shenton, 2004). Furthermore, focus group accounts were sent for member checking as a way of validating the findings captured as true reflection of their views (Bygstad \& Munkvold, 2007).

\section{RESULTS AND DISCUSSION}

The aim of this study was to reveal the extent to which in-service teacher professional development met the intended goal of improving mathematics teaching and learning during the implementation of NCS. A focus group discussion with five mathematics teachers at each of the ten secondary schools was conducted to obtain descriptions on the circumstances and conditions under which the participants were exposed to professional development before and during NCS implementation in order to access its influence on Mathematics teaching and learning. Therefore, the study responded to the question: To what extent was teacher professional development relevant to the Mathematics teaching and learning during the implementation of NCS? The study revealed that the professional development that teachers experienced never impacted their teaching practices. This is informed by the study data which revealed two themes: 1) the presenter-talk method used in workshops was divorced from classroom situation and 2) shift from cascade model of professional development to a model where learning for teachers is a daily routine. A discussion of these themes follows.

\section{1) The presenter-talk method used in workshops was divorced from classroom situation}

During the discussions and with reference to the effectiveness of teacher professional development, teachers refuted the manner in which the workshops were conducted:

T_2: “... It is unfortunate that teachers are summoned for a workshop only to be given materials or should I call them individual study materials ... which are first read to us by the presenters ... then why calling a workshop instead of just sending the materials to schools and spare teachers from wasting valuable teaching time for nothing." 
T_7: “... All other things being equal, if these workshops were effective we could have witnessed a marked increase in student achievement in mathematics ... So if the workshops cannot support our ongoing growth and development then it relinquishes significant opportunities to influence teacher practice and student achievement. So they (the DoE) should change their workshop models and give teachers a chance to workshop themselves under their watchful eye ..."

Focusing on discussions with teachers, teachers of Mathematics desire workshops that are offered by "one of their own", as suggested by some of them:

T_1: “... Mathematics is a practical subject. So listening to a presenter from one of these universities will not improve how we should teach the subject ... In my view, we should workshop ourselves ... by which I mean, to the topics that are said to be problematic, there are classroom teachers who have the knowledge of these topics and I would like them to teach the topic while other teachers observe and learn and then open a discussion with the help of the university presenters ... that way teachers will learn far much better."

T_48: “... These teacher professional development workshops are disconnected from classroom practices ... Seeing someone teaching, as if students are there, provides us with richer knowledge and more informed and practical strategies for improving teaching practices ..."

Based on the views of the teachers, the presenter-talk method characterizes the workshops. In such a case, teachers did not see any reason for embarking on a different approach in their classroom besides the teacher-talk method, because that is the method advanced at workshops. These suggestions by teachers clearly indicate that teachers dislike the top-down decision-making mode of running the district. This implies that conducting preworkshop interviews with participants is an essential factor in improving the culture of workshops. Teachers are aware that their professional knowledge and skills should be up to date always, but the presenter-talk method used in workshops is divorced from their classroom situation. They are advocating for effective teacher professional development.

2) Shift from cascade model of professional development to a model where learning for teachers is a daily routine

The 'one shot', 'sit and get' presentation-style workshops have no impact in the process of teaching and learning because much of the information gained is not likely to be applied once teachers return to their daily routine (Hunzicker, 2010). This is so because teachers are held responsible for their students' performance regardless of other factors that may affect it. Here, for them, impact-oriented concerns take precedence over trying out new approaches of learning. During the discussions, one teacher argued:

T_41: “...Dentists are not held responsible for cavities when youngsters don't brush their teeth but when students underperform on high-stake tests, we are held responsible regardless of other factors that may affect it. ... Tests have become the sole indicator of teaching effectiveness... so we focus on both highand low-stakes exit examinations than to try out these other new approaches of teaching..."

High-stakes testing here refers to standardized tests developed for the purpose of evaluating students and judgments about student, teacher, and school effectiveness often are based on the performance on these tests by students. Passing could bring rewards to teachers (bonuses) and schools (positive publicity or accolades). Whereas failure could lead to schools being labelled dysfunctional and may face closure or take-over, and to students denied entry to universities or retained in grade. Based on this and on T_41's assertion, high-stakes testing has impacted teaching and learning practices. The intended and unintended impact of high-stakes testing suggest that the practice of high-stakes testing has eroded and undermined sound educational practice. In their quest to avoid public humiliation, teachers narrow the curriculum to just what is tested, and spend time in test preparation instead of genuine instruction. One explanation for this state of affairs is tests influence how and what teachers would teach and how and what students would learn. This suggests that as the pressure to perform on high-stakes test rises, so too do undesirable educational practices. Therefore, re-conceptualizing professional development to align with the challenges teachers face allows them to shift their efforts from teacher-talk method to a different approach in their classroom. Hunzicker (2011) suggests that "effective teacher professional development should: consider the needs, concerns, and interests of individual teachers along with those of the school; be relevant and authentic (Jobembedded); involve the study and application of content and pedagogy with emphasis on student Learning Outcomes; engage teachers in both active and interactive learning; and be a combination of contact hours, duration and coherence" (p.178). So "teacher professional development was found to improve teachers' effectiveness when: focused on teaching specific parts of the curriculum; occurred over time; engaged teachers in a professional community of practice; offered relevant expertise; focused on methods to improve student outcome and when school authorities support teachers' opportunities to learn and process new information" (Timperley, Wilson, Barrar \& Fung, 2007). Besides, professional learning occurs within people who live and work in unique contexts that can either thwart or support professional development (Blank, De las Alas \& Smith, 2008). Therefore, a school- 
based professional development, teacher facilitated (with support materials) in which all teachers participate, would be productive. This is likely to be more effective because it often is led by current classroom teachers (as advocated by T_1), whom other teachers trust as a source for meaningful guidance on improving teaching (Blank et al., 2008). Thus teacher concerns can guide the selection of strategies for professional development and provide insight into the content of the strategies. This may, in turn, help address teachers' needs and concerns as they try out new approaches to learning. For example, to "increase teachers' content knowledge so they can provide more enquiry or problem solving approaches in mathematics classes, the designer might choose to first offer teachers an immersion experience in mathematics. Thereafter, workshops that help raise teachers' awareness of what new teaching practices look (and feel) like in action. As they practice new moves in their classrooms, they need opportunities to meet with other teachers to discuss what is working and how to make refinements" (Meijs et al., 2016: 91). A shift from the 'one shot,' 'sit and get' model to a model where learning for teachers is a daily routine is all what the teachers are calling for. This is so because teachers approach learning with clear objectives, using their teaching skills to incoperate new teaching strategies. They are encouraged by prospects of addressing problems encountered during their teaching experiences. Therefore, drawing from the discussions with teachers, it is evident that they favour unrestricted learning activities and learn better when they have a voice in the learning process. This may make change in teaching practice more likely. Therefore, professional development that brings change is anything that involves teachers in learning activities that are supportive, job-embedded, instructionally focused, collaborative, and ongoing (Hunzicker, 2011; Meijs et al., 2016).

Teacher professional development such as lesson study, whose salient feature is that teachers are collaboratively engaged in action research in order to improve teaching (Ono, 2008), would probably suit the teachers' concerns as revealed by the discussion data. The essence of lesson study is that teachers plan lessons collaboratively and the lesson is then taught by one of the teachers while being observed by the other teachers. Afterwards, the teachers discuss the lesson. This approach allows teachers to realize that there is something wrong with their current teaching practices. This may encourage them to succeed in content and methods that initially seemed foreign to them. According to Hill and Ball (2009), good teachers are familiar with content and how students should learn that content. This suggests that teachers who can discuss their teaching with knowledgeable colleagues offer students a better diet. Thus, "it is posited that professional development activities that focus on how well a teacher uses mathematical and pedagogical knowledge to help students learn mathematics", would go a long way to improving the level of teaching of mathematics.

\section{CONCLUSION}

The study data revealed that the professional development that teachers experienced never impacted their teaching practices. Teachers strongly disapproved the manner in which the workshops were conducted claiming they were disconnected from classroom practices. This was despite the numerous in-service preparation sessions teachers were exposed to (prior to and during implementation of NCS) and the various materials hand-outs. Factors that may have led to the unsuitability of the cascade model of professional development are that the schedule and structure of professional development did not allow teachers to reflect among themselves; nor for them to initiate and direct their collegial; nor initialize their own professional learning; no formal follow-up was done to evaluate the impact of such in-service program. Hence the cascade model of professional development did not suit the teachers. Based on this, "the conclusion was that: (a) the success of in-service programs should not be determined by merely making sure all teachers attend the teacher development programs. Instead, the way that the ideas, knowledge and skills learnt are implemented in a classroom setting is a crucial measure of the success of such a program; (b) for any in-service program to be successful, especially one that introduces teachers to a different instructional approach from the traditional one, it has to impact on teachers' concerns (be they self-oriented, taskoriented or impact-oriented)". Therefore the recommendation is that teacher professional development should not just be thought of as presenter-talk driven workshops, but also as instances of engaging teachers in activities that connect their daily responsibilities such as planning lessons and constructing assessments. As such, activities such as coaching, mentoring and study groups can be used to engage teachers in activities. In this way teachers working together to examine practice and exchanging ideas about teaching would come to value collegiality among themselves and teacher expertise.

\section{REFERENCES}

ASCD (2010). Association for Supervision and Curriculum Development: On-site staff development. Retrieved from http:/ / webserver3.ascd.org/ossd/actionresearch.html

Attard, K. (2017). Personally driven professional development: reflective self-study as a way for teachers to take control of their own professional development. Teacher Development, 21(1), 40-56. https:// doi.org/10.1080/13664530.2016.1218363 
Bett, H. K. (2016). The cascade model of teachers' continuing professional development in Kenya: A time for change? Cogent Education, 3(1), 1139439. https:/ / doi.org/10.1080/2331186X.2016.1139439

Blank, R. K., De las Alas, N., \& Smith, C. (2008). Does teacher professional development have effects on teaching and learning? Analysis of evaluation findings from programs for mathematics and science teachers in 14 states. Washington, DC: Council of Chief State School Officers.

Bygstad, B., \& Munkvold, B. (2007). The significance of member validation in qualitative analysis: experiences from a longitudinal case study. Proceedings of the $40^{\text {th }}$ Hawaii International Conference on System Sciences. Thousand Oaks, CA: Sage. https:// doi.org/10.1109/HICSS.2007.553

Bygstad, B., \& Munkvold, B. E. (2007, January). The significance of member validation in qualitative analysis: Experiences from a longitudinal case study. In System sciences, 2007. hicss 2007. 40th annual hawaii international conference on (pp. 243b-243b). IEEE.

Colaizzi, P. F. (1978). Psychological research as the phenomenologist views it.

Covay Minor, E., Desimone, L., Caines Lee, J., \& Hochberg, E. D. (2016). Insights on How to Shape Teacher Learning Policy: The Role of Teacher Content Knowledge in Explaining Differential Effects of Professional Development. Education policy analysis archives, 24(61). https:/ / doi.org/10.14507/ epaa.24.2365

Creswell, J. W., \& Clark, V. L. P. (2017). Designing and conducting mixed methods research. Sage publications.

Donnell, L. A., \& Gettinger, M. (2015). Elementary school teachers' acceptability of school reform: Contribution of belief congruence, self-efficacy, and professional development. Teaching and teacher education, 51, 47-57. https:/ / doi.org/10.1016/j.tate.2015.06.003

Easton, L. B. (2009). Protocols for professional learning. Alexandria, VA: Association for Supervision and Curriculum Development.

Fiske, E. B., \& Ladd, H. F. (2004). Elusive equity: education reform in post-apartheid South Africa. Washington, DC: Brookings Institute.

Gaudin, C., \& Chaliès, S. (2015). Video viewing in teacher education and professional development: A literature review. Educational Research Review, 16, 41-67. https:/ / doi.org/10.1016/j.edurev.2015.06.001

Giorgi, A. (Ed.). (1985). Phenomenology and psychological research (pp. 8-22). Pittsburgh, PA: Duquesne University Press.

Gunnarsdóttir, G. H., \& Pálsdóttir, G. (2010). Lesson study in teacher education: A tool to establish a learning community. Retrieved from http://www.cerme7.univ.rzeszow.pl/WG/17a/CERME7_WG17A_ Gunnarsdottir\%26Palsdottrl.pdf

Heck, R. H. (2007). Examining the relationship between teacher quality as an organizational property of schools, and students' achievement and growth rates. Administration Quarterly, 43(4), 399-432. https://doi.org/10.1177/0013161X07306452

Heck, R. H. (2009). Teacher effectiveness and student achievement: Investigating a multilevel cross-classified model. Journal of Educational Administration, 47(2), 227-249. https:/ / doi.org/10.1108/09578230910941066

Heppner, P. P., \& Heppner, M. J. (2004). Writing and publishing your thesis. DissertationE Research: A guide for students in the helping professionals, (4thEds), Thomson Brooks/Cole: Canada.

Hill, H., \& Ball, D. (2009). The curious--and crucial--case of mathematical knowledge for teaching. Phi Delta Kappan, 91(2), 68-71. Retrieved from http:/ / www.pdkintl.org/ https:/ / doi.org/10.1177/003172170909100215

Hord, S. M., \& Tobia, E. F. (2015). Reclaiming our teaching profession: The power of educators learning in community. Teachers College Press.

Hunzicker, J. L. (2010). Characteristics of effective professional development: a checklist. [online]. Retrieved from ERIC database (ED510366). Retrieved from http:/ / www.eric.ed.gov/PDFS/ED510366.pdf

Hunzicker, J. L. (2011). Characteristics of effective professional development: a checklist. Professional Development in Education, 37(2), 177-179. https:/ / doi.org/10.1080/19415257.2010.523955

Jansen, J. D., \& Christie, P. (eds) (1999). Changing curriculum: studies on outcomes-based education in South Africa. Cape Town: Juta.

Jansen, J. D., \& Taylor, N. (2003). Educational change in South Africa 1994-2003: case studies in large scale education reform. Washington DC: World Bank.

Joubert, M., \& Sutherland, R. (2008). Researching CPD for teachers of mathematics: A review of the literature. National Centre for Excellence in the Teaching of Mathematics.

Kennedy, A. (2005). Models of continuing professional development: A framework for analysis. Journal of in-service education, 31(2), 235-250. https:/ / doi.org/10.1080/13674580500200277 
Krathwohl, D. R. (2004). Methods of educational and science research: an integrated approach (2nd Ed.). Thousand Oaks, CA: Sage.

Lee, H. L. (2007). Developing an effective professional development model to enhance teachers' conceptual understanding and pedagogical strategies in mathematics. Journal of Educational Thought, 41(2), 125-144.

Lewis, C. (2008). Lesson study. In Easton, L.B. Powerful designs for professional learning. Oxford, OH: National Staff Development Council.

Lodico, M., Spaulding, D., \& Voegtle, K. (2006). Methods in educational research: From Theory to practice. San Francisco: Jossey-Bas.

Loucks-Horsley, S., Hewson, P. W., Love, N., \& Stiles, K. E. (1998). Designing Professional Development for teachers of science and mathematics. Thousand Oaks, CA: Corwin.

Loucks-Horsley, S., Stiles, K. E., Mundry, S., Hewson, P. W., \& Love, N. (2010). Designing Professional Development for Teachers of Science and Mathematics (3rd Ed.). Thousand Oaks, CA: Corwin.

McAleavy, T., \& Elwick, A. (2016). School Improvement in London: A Global Perspective. Education Development Trust.

Meijs, C., Prinsen, F. R., \& de Laat, M. F. (2016). Social learning as approach for teacher professional development: how well does it suit them? Educational media international, 53(2), 85-102. https:/ / doi.org/10.1080/09523987.2016.1211333

Nelson, B. S., \& Sassi, A. (2007). What math teachers need most. The Education Digest, 72(6), 54-56.

Ono, Y. (2008). Lesson study as professional development of teachers in South Africa and in Afghanistan. Paper presented at the Comparative and International Education Society 52nd Annual Conference, Teachers College, New York.

Ono, Y., \& Ferreira, J. (2010). A case study of continuing teacher professional development through lesson study in South Africa. South Africa Journal of Education, 30(1), 4-10.

Periodical Teachers' News Letter (October, 2010). The Teacher News Paper.

Salleh, H. (2016). Facilitation for professional learning community conversations in Singapore. Asia Pacific Journal of Education, 36(2), 285-300. https:/ / doi.org/10.1080/02188791.2016.1148855

Shank, G. D. (2006). Qualitative research: A personal skills approach. Pearson Merrill Prentice Hall.

Shenton, A. K. (2004). Strategies for ensuring trustworthiness in qualitative research projects. Education for information, 22(2), 63-75. https:/ / doi.org/10.3233/EFI-2004-22201

Shulman, L. S. (1986). Those who understand: Knowledge growth in teaching. Educational researcher, 15(2), 4-14. https:/ / doi.org/10.3102/0013189X015002004

Strauss, A., \& Corbin, J. (1998). Basics of qualitative research: Procedures and techniques for developing grounded theory.

Stronge, J. H. (2007). Qualities of effective teachers (2nd Ed.). Alexandria, VA: Association of Supervision and Curriculum Development.

Tam, A. C. F. (2015). The role of a professional learning community in teacher change: A perspective from beliefs and practices. Teachers and Teaching, 21(1), 22-43. https:// doi.org/10.1080/13540602.2014.928122

Taylor, N., \& Vinjevold, P. (1999). Getting learning right: report to the president's education initiative research project. Johannesburg: Joint Education Trust.

Timperley, H., Wilson, A., Barrar, H., \& Fung, I. Y. Y. (2007). Teacher Professional Learning and Development: best evidence synthesis iteration. (Wellington, New Zealand Ministry of Education.

Trust, T., \& Horrocks, B. (2017). 'I never feel alone in my classroom': teacher professional growth within a blended community of practice. Professional Development in Education, 43(4), 645-665. https:/ / doi.org/10.1080/19415257.2016.1233507

Van Tassel-Baska, J. (2005). Lessons learned from curriculum differentiation, instruction, and assessment. Presentation at the National Curriculum Network Conference, Williamsburg, VA.

Wiliam, D. (2008). Changing classroom practice. Educational leadership, 65(4), 36-41.

\section{http://www.ejmste.com}

